\begin{tabular}{|c|c|c|}
\hline 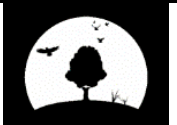 & Our Nature & $\begin{array}{l}\text { ISSN: 1991-2951 (Print) } \\
\text { ISSN: 2091-2781 (Online) }\end{array}$ \\
\hline $\begin{array}{l}\text { Noture Consenation \& } \\
\text { Hedith Crave Council }\end{array}$ & Journal homepage: http://nepjol.info/index.php/ON & (c) (1) () () \\
\hline
\end{tabular}

\title{
Relative condition factor, length-weight relationship and sex ratio of copper mahseer, Neolissochilus hexagonolepis (McClelland, 1839) from Tamor River, Nepal
}

\author{
Suren Subba ${ }^{*}$, Bharat Raj Subba ${ }^{2 * *}$ and Vinod K. Mahaseth ${ }^{3 * * *}$ \\ ${ }^{1}$ Department of Zoology, IOST, Dhankuta Multiple Campus, Tribhuvan University, Dhankuta, Nepal. \\ ${ }^{2}$ Department of Zoology, Post Graduate Campus, Tribhuvan University, Biratnagar, Nepal \\ ${ }^{3}$ Department of Zoology, Mahendra Morang Adarsh Multiple Campus, Tribhuvan University, Biratnagar, \\ Nepal. \\ *E-mail: surensubba35@yahoo.com \\ **E-mail: subbabharatraj@gmail.com \\ *E-mail:vkmahaseth1962@gmail.com
}

\begin{abstract}
The present investigation was carried out for establishing the length weight relationship and to enumerate the relative condition factor and the sex ratio of Neolissochilus hexagonolepis from Tamor River, Nepal. Altogether 198 fishes were investigated from December 2014 till the end of November 2016. The sex ratio of the fish was found to be in the ratio of 1:1.2 with female dominating the catch for most parts of the year. Analysis of t-test showed a highly significant relationship $(\mathrm{p}<0.05)$ between length and weight for male, female and sexes pooled. The fish was found to show isometric growth pattern with exponential value (b) equal to 2.962 for sexes pooled. The mean value of Fulton's condition factor (K) for sexes pooled was found to be $1.29 \pm 0.49$ giving the indication that the general well being of the fish was good. Sudden increase in the value of relative condition factor $(\mathrm{Kn})$ in the size group 30-33 cm in male and $42-45 \mathrm{~cm}$ in female indicated their length range during which they showed the sign of maturation for the first time. Steep fall in the value of ' $\mathrm{Kn}$ ' in size groups $33-36 \mathrm{~cm}$ onwards in male and $45-48 \mathrm{~cm}$ in female indicated their length range at spent phase.
\end{abstract}

Keywords: Cube law, Allometric growth, Isometric growth, Fulton's condition factor, General well being

DOI: http://dx.doi.org/10.3126/on.v16i1.21569

Manuscript details: Received: 11.04.2018 / Accepted: 03.08.2018

Citation: Subba,S. B.R. Subba and V. K. Mahaseth 2018. Relative condition factor, length-weight relationship and sex ratio of copper mahseer, Neolissochilus hexagonolepis (McClelland, 1839) from Tamor River, Nepal, Our Nature 16(1): 27-34. DOI: http://dx.doi.org/ 10.3126/on.v16i1.21569

Copyright: () Subba, Subba and Mahaseth 2018. Creative Commons Attribution - Non Commercial 4.0 International License.

\section{Introduction}

The study area for this research is the Tamor river which is a major river in eastern Nepal. This river lies in the latitude and longitude coordinates of $26^{\circ} 54^{\prime} 46.80^{\prime \prime} \mathrm{N}$ and $87^{\circ} 09^{\prime} 25.20^{\prime \prime} \mathrm{E}$ respectively (Google maps, 2014). This river meets the confluence of Arun and Sunkoshi at Tribenighat to drain into the giant Saptakoshi which flows through Mahabharat Range on to the Gangetic plain. The total length of this river is about $190 \mathrm{~km}$ with $5817 \mathrm{~km}^{2}$ catchment area (Shrestha et al, 2009).

Tamor river serves as the source of livelihood to hundreds of people in this region who depend on it for domestic use and for irrigation purpose. It is a good source for capture fisheries and forms the lifeline for the rural economy of this region. This river is the home as well as the breeding ground for many species of 
fishes. Shrestha et al. (2009) reported 30 species of fishes from this river. The river also serves as the suitable home ground and breeding ground for Neolissochilus hexagonolepis.

Neolissochilus hexagonolepis, locally known as Katle, is one among the dominating species in snow fed torrential rivers of Nepal. Unfortunately, its population is in sharp decline due to the loss of its habitat and overexploitation. Removal of sand and gravels from river beds, rampant use of pesticides and insecticides in agricultural fields and their seepage into the river, over fishing and other anthropogenic activities which degrade its habitat may all be contributing to its steep decline in recent years.

Growth of a fish is defined as the change in size with reference to time and weight is expressed as a function of length (Dars et al., 2010). Growth in fish continues throughout its life, although it becomes slower after the onset of sexual maturity. Growth rates and size achieved by fish are highly flexible and subject to both genetic and environmental controls, so that the size reached may vary with environmental variables, such as water temperature and food availability (Mc Dowall, 1994).

Length- weight relationship studies of any fish species is a pre-requisite for assessing its population characteristics (Le Cren, 1951). The length- weight relationship indicates the degrees of stabilization of taxonomic characters in fish species and is useful in the management and exploitation of fish populations (Pervin and Mortuza, 2008).

Several ichthyologists have studied lengthweight relationship of fishes from different environmental conditions. The relationship with regard to Neolissochilus hexagonolepis was studied by Devashish et al. (2005). Recently, Lydia et al. (2015) gave an account on the length- weight relationship and condition factor of the same species from Meghalaya, India.

As with other species, Pervin and Mortuza (2008) investigated the length -weight relationship of a fresh water fish, Labeo boga (Hamilton), from India. Similarly, Abobi (2015), Ozcan and Altun (2015) and Adaka et al. (2017) gave an account on the length-weight relationship of fresh water fish species from the rivers of Ghana, Pakistan and Nigeria respectively.

The length- weight relationship in fish is generally expressed by the equation, $\mathrm{W}=\mathrm{aL}^{\mathrm{b}}$; where, $\mathrm{W}$ is the weight of the body, $\mathrm{L}$ represents its length and ' $a$ ' (regression intercept) and 'b'(regression slope) are constants. In fishes, generally the growth pattern follows the cube law (Brody, 1945; Lagler 1952) but the actual relationship may depart from this (Le Cren, 1951). When the value of regression coefficient (b) is equal to 3 , the growth in fish is said to be isometric during which there is no change in the shape of the body as the fish grows. The values departing from 3 indicate the allometric growth patterns; negative allometry when the value is less than 3 and positive allometry when the value is more than 3. This is known as the cube law. In case of negative allometric growth the fish becomes more slender as it increases in weight whilst in the case of positive allometric growth the fish becomes relatively stouter or deep bodied as it increases in length.

The length-weight relationships may depart from the cube law due to seasonal fluctuation in environmental parameters, physiological condition of the fish at the time of collection, gonadal development and nutritive condition of the environment of the fishes (Lydia et al., 2015).

The condition factor and its assessment find a great application in fisheries science. It is used to understand the overall condition of the fish, the fatness or well-being of fish. The enumeration of the condition factor is based on the hypothesis that the heavier fish of a given length is in better condition (Das et al., 2017).

Several ichthyologists emphasized the significance of the condition factor in fisheries science. Fulton's condition factor is widely used in fisheries and fish biology and that condition factors are important parameters for the evaluation of fish stocks (Ozcan and Altun, 2015). Similarly, Araneda et al. (2008) opined that the information on condition factor can be vital to culture system management as it provides the information on the specific conditions under which the organisms are developing. Their opinion focuses on the fact that the evaluation of the condition factor not only is useful in monitoring the health condition of the fish under investigation but, proves its usefulness far beyond that by providing clear picture of the environment in which the fish are living.

Neolissochilus hexagonolepis is considered as a near threatened species and hence due care and attention should be given for its conservation (Arunachalam, 2010). 


\section{Materials and methods Samples collection}

Fish sampling was carried out for two years commencing from the second week of December 2014 till the end of November 2016. Samples were collected from the catch landings of fishermen who used hooks, cast net, gill net, traps and other conventional local techniques for catching the fishes. Sampling was done along the river at the stretch of $10 \mathrm{~km}$ upstream and downstream (Fig. 1).

The samples were sexed and total weight and total length measured for each of the collected specimen. Total weight (including gut and gonads) was measured using a digital balance with the precision of $0.01 \mathrm{~g}$. Total length was measured from the tip of snout to the distal tip of the longest caudal fin ray. The measurement was taken in full stretched condition to the nearest $1 \mathrm{~mm}$ using a measuring tape and graduated ruler. Verification of sex of the samples was made through examination of gonads in situ after dissection. Total number of males and females were pooled for each month and ratio calculated.

All the data were recorded on specific data collection sheets.

\section{Length-weight relationship (LWRs)}

The length-weight relationship of the fish under investigation was worked out as per cube law given by Le Cren (1951).

$$
\mathrm{W}=\mathrm{aL}^{\mathrm{b}}
$$

Where, $\mathrm{W}$ is the weight of the fish, $\mathrm{L}$ represents the observed total length of the fish, ' $a$ ' is the regression intercept and ' $b$ ' is the regression slope.

The logarithmic transformation of the above equation is:

$\log W=\log a+b \log L$

The length-weight (Log - transformed) relationships were determined by linear regression analysis for male, female and sexes pooled.

Relationship equations were established by least square method and the coefficient of correlation ( $r$ ) was calculated by standard statistical formula.

Scatter plot diagrams were plotted for total weight and lengths of the fishes. All the data on LWR of the fish were subjected to t-test analysis at $\mathrm{P}<0.05$. Statistical software SPSS 16 was used for analyzing the data.

\section{Condition factor (K)}

The Fulton's condition factor (K) was computed by using the following equation:

Condition factor $(\mathrm{K})=\mathrm{W} * 100 / \mathrm{L}^{3}$

Where, $\mathrm{W}$ is the total weight of the fish (in gram), $\mathrm{L}$ is the length of the fish (in $\mathrm{cm}$ ) and the number 100 is the factor bringing the condition factor near to unity.

\section{Relative condition factor (Kn)}

The equation used for relative condition factor was:

$$
\mathrm{Kn}=\mathrm{W} / \mathrm{w}
$$

Where $\mathrm{W}$ is the observed weight of the fish (in grams) and $\mathrm{w}$ is the calculated weight for the observed length (in grams). The calculated weight for the observed length is obtained from the equation $\mathrm{w}=\mathrm{a}^{*} \mathrm{~L}^{\mathrm{b}}$, where $\mathrm{a}$ and $\mathrm{b}$ are the exponential form of the intercept and slope, respectively, of the logarithmic length-weight equation.

The relative condition factor $(\mathrm{Kn})$ was calculated for all the fish samples from the average lengths and weights of $3 \mathrm{~cm}$ interval of total lengths. As there was significant difference in the length-weight relationship between males and females the relative condition factor $(\mathrm{Kn})$ values were computed separately for both the sexes.

\section{Results and discussion}

Neolissochilus hexagonolepis is one among the dominating species in the torrential rivers of the hilly region of the country. However, its population is in sharp decline during recent years. The present investigation was carried out to unravel the prevailing situation of the fish in Tamor river so as to work out the ways for its conservation in the days to come.

Altogether 89 male and 109 female N. hexagonolepis were investigated during the study period with the male to female sex ratio as 1:1.2. Females dominated the total catch for most parts of the year. Similar result was reported by Swar (1994) for reservoir population of Katle. However, he reported higher number of males than females for riverine population for a couple of years and attributed this imbalance to a number of factors including differences in age composition due to higher mortality in the males and asynchronous spawning migrations. Jyrwa and Bhuyan (2017) reported the lesser abundance of females than males and attributed it to the differential occurrence of the males and females in various water columns suggesting that 


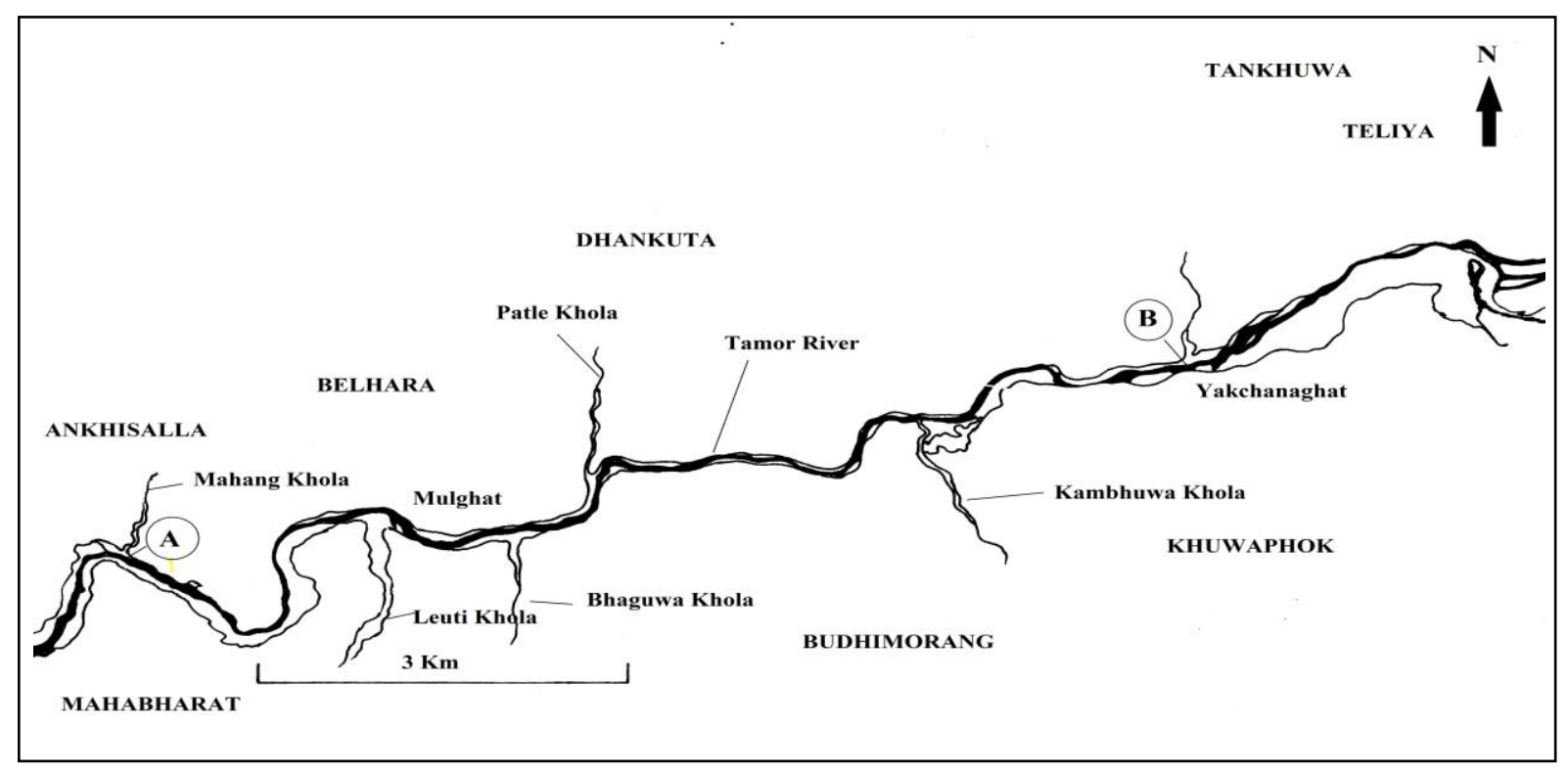

Figure 1. Map of the Tamor River showing sampling area from A to B.

the females live in deeper areas making them less available during the catching effort. Short distance asynchronous migration of Katle to spawning grounds caused a significant change in the proportions of males to females during the study period.

The total weight of male and female fishes ranged from $19.11 \mathrm{~g}$ to $750 \mathrm{~g}$ and $24 \mathrm{~g}$ to $1500 \mathrm{~g}$ with a mean of $171.67 \pm 186.78 \mathrm{~g}$ and $349.23 \pm$ $316.82 \mathrm{~g}$ respectively. The total length of male and female fish ranged from $12.4 \mathrm{~cm}$ to $36.9 \mathrm{~cm}$ and $13 \mathrm{~cm}$ to $46.3 \mathrm{~cm}$ with a mean of $21.21 \pm$ $6.38 \mathrm{~cm}$ and $27.86 \pm 9.21 \mathrm{~cm}$ respectively.

Analysis of t-test showed a highly significant relationship $(\mathrm{p}<0.05)$ between length and weight for male, female and sexes pooled (Table 1).

The computed regression coefficient (b) values for the relationships between total weight and total length came to be 2.977 for female fish (Fig. 2) and 3.052 for male fish (Fig. 3). Similarly, for sexes pooled the value was estimated to be 2.962 (Fig. 4).

The total weight and total length of Katle from the river showed strong positive correlation for both the sexes and the high values of correlation coefficients $(r>0.8)$ depicted high precision of the relationships between all the parameters. Devashish et al. (2005) and Lydia et al. (2015) also reported a high significant correlation between the length and weight for the species.

During the present investigation, the exponential value of the length-weight relationship 'b' followed the cube law (Sex pooled data: 2.962), which in general indicated that the fish showed isometric growth pattern. However, sex-wise, while female showed isometric growth pattern $(b=2.977)$ the value for male $(b=3.052)$ deviated slightly from the ideal value, being little more than 3, suggesting positive allometric growth. Devashish et al. (2005) and Lydia et al. (2015) also reported isometric as well as allometric growth pattern for the species.

The variation in the ' $b$ ' value for the same species could be attributed to the difference in sampling, sample size or length ranges (Hossain, 2010). Lydia et al. (2015) suggested that the length-weight relationships may depart from the cube law due to seasonal fluctuation in environmental parameters, physiological condition of the fish at the time of collection, gonadal development and nutritive condition of the environment of the fishes.

As with some other species, similar deviations from the cube's law were also reported in Labeo calbasu from Soni river ( Pathak, 1975), in Rasbora daniconius from Karnataka (Kumar et al. 2005) and in Puntious filamentosus from Chalakudy river, Kerela (Prasad and Ali, 2007). The mean value of Fulton's condition factor $(\mathrm{K})$ for sexes pooled was found to be $1.29 \pm 0.491$ which is greater than 1. This gave the indication that their general well being was good. Similar findings were also reported by Lydia et al. (2015) and Devashish et $a l$. (2005) for the same species. 
Table 1. Regression parameters of the length-weight relationship $\left(\mathrm{W}=\mathrm{aL}^{\mathrm{b}}\right)$ of Katle from Tamor River, Nepal

\begin{tabular}{|c|c|c|c|c|c|c|c|c|c|c|c|c|}
\hline \multirow[b]{2}{*}{ Sex } & \multirow[b]{2}{*}{$\mathrm{N}$} & \multicolumn{3}{|c|}{ Weight range $(\mathrm{gm})$} & \multicolumn{3}{|c|}{ Length range $(\mathrm{cm})$} & \multirow[b]{2}{*}{$\mathrm{a}$} & \multirow[b]{2}{*}{ b } & \multirow[b]{2}{*}{$\mathrm{r}$} & \multirow[b]{2}{*}{ t-test } & \multirow[b]{2}{*}{$\mathrm{p}$-value } \\
\hline & & $\min$ & $\max$ & $\begin{array}{c}\text { Mean } \pm \\
\text { S.D. }\end{array}$ & $\min$ & $\max$ & S.D. & & & & & \\
\hline Female & 109 & 24 & 1500 & $\begin{array}{c}349.23 \\
\pm 316.82 \\
\end{array}$ & 13 & 46.3 & $\begin{array}{l}27.86 \\
\pm 9.21 \\
\end{array}$ & 0.012 & 2.977 & $0.89 * * *$ & $4.89 \mathrm{E}-19$ & $\begin{array}{c}6.0157 \mathrm{E}-38 \\
\text { S }\end{array}$ \\
\hline Male & 89 & 19.1 & 750 & $\begin{array}{c}171.67 \\
\pm 186.78 \\
\end{array}$ & 12.4 & 36.9 & $\begin{array}{l}21.21 \\
\pm 6.38 \\
\end{array}$ & 0.010 & 3.052 & $0.81 * * *$ & $1.11 \mathrm{E}-11$ & $\begin{array}{c}4.01795 \mathrm{E}-22 \\
\mathrm{~S}\end{array}$ \\
\hline $\begin{array}{l}\text { Sexes } \\
\text { pooled }\end{array}$ & 198 & 19.1 & 1500 & $\begin{array}{c}269.42 \\
\pm 280.09\end{array}$ & 12.4 & 46.3 & $\begin{array}{l}24.87 \\
\pm 8.70\end{array}$ & 0.013 & 2.962 & $0.88 * * *$ & $\begin{array}{c}3.5719 \mathrm{E}- \\
27\end{array}$ & $\begin{array}{c}1.09821 \mathrm{E}-65 \\
\text { S }\end{array}$ \\
\hline
\end{tabular}

$\mathrm{N}=$ sample size, S.D. $=$ Standard deviation, ${ }^{* * *}$ shows strong correlation $(\mathrm{r}>0.70), \mathrm{S}=$ significant at $5 \%$ level $(\mathrm{p}<0.05)$
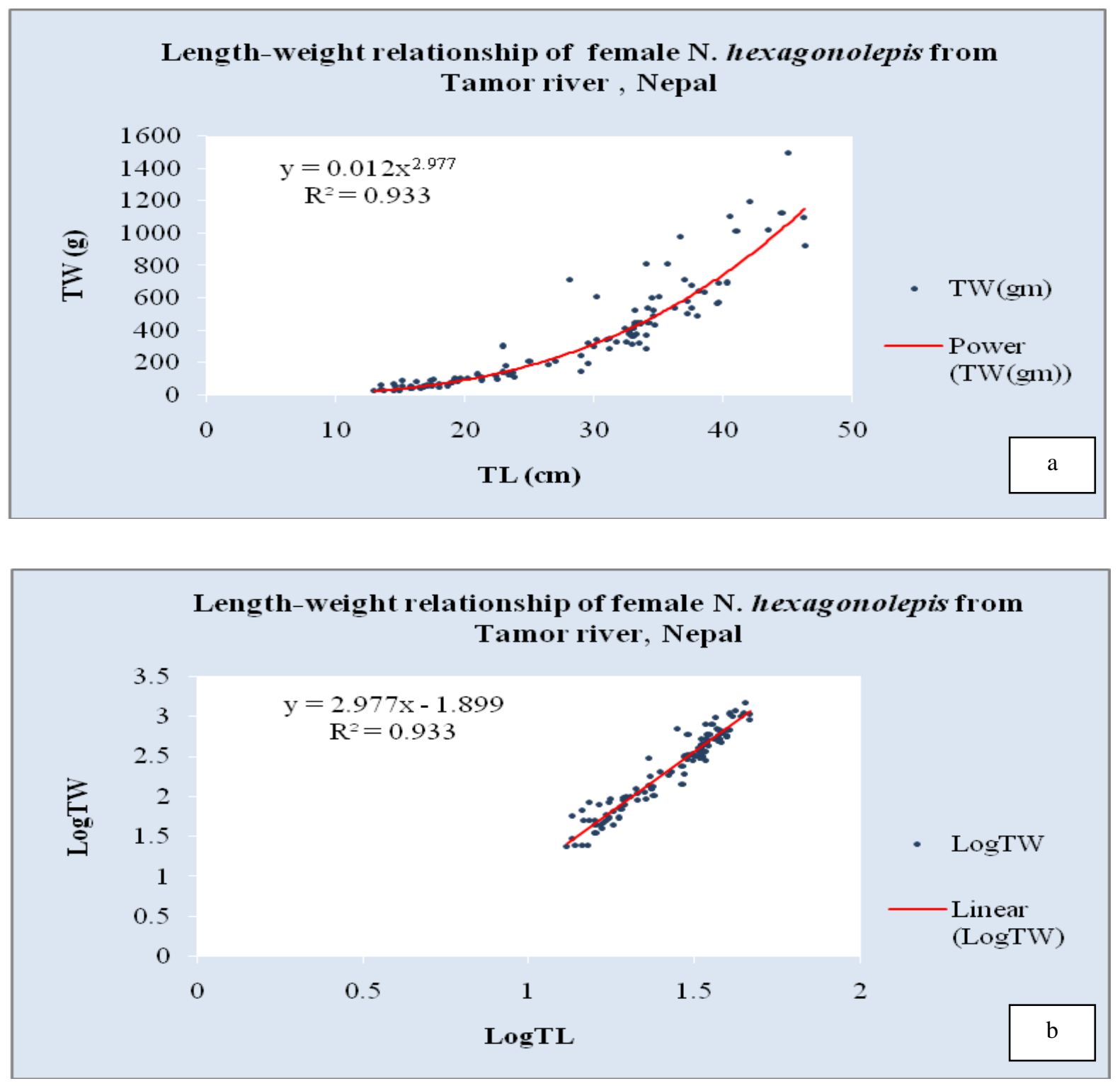

Figure 2. Length- weight (TW-TL) relationships of female $N$. hexagonolepis from Tamor river: parabolic form (a) TW=0.012 TL 2.977 and linear form (b) Log TW $=-1.899+2.977 \mathrm{Log} \mathrm{TL}$ 
Subba, Subba and Mahaseth / Our Nature (2018), 16 (1): 27-34
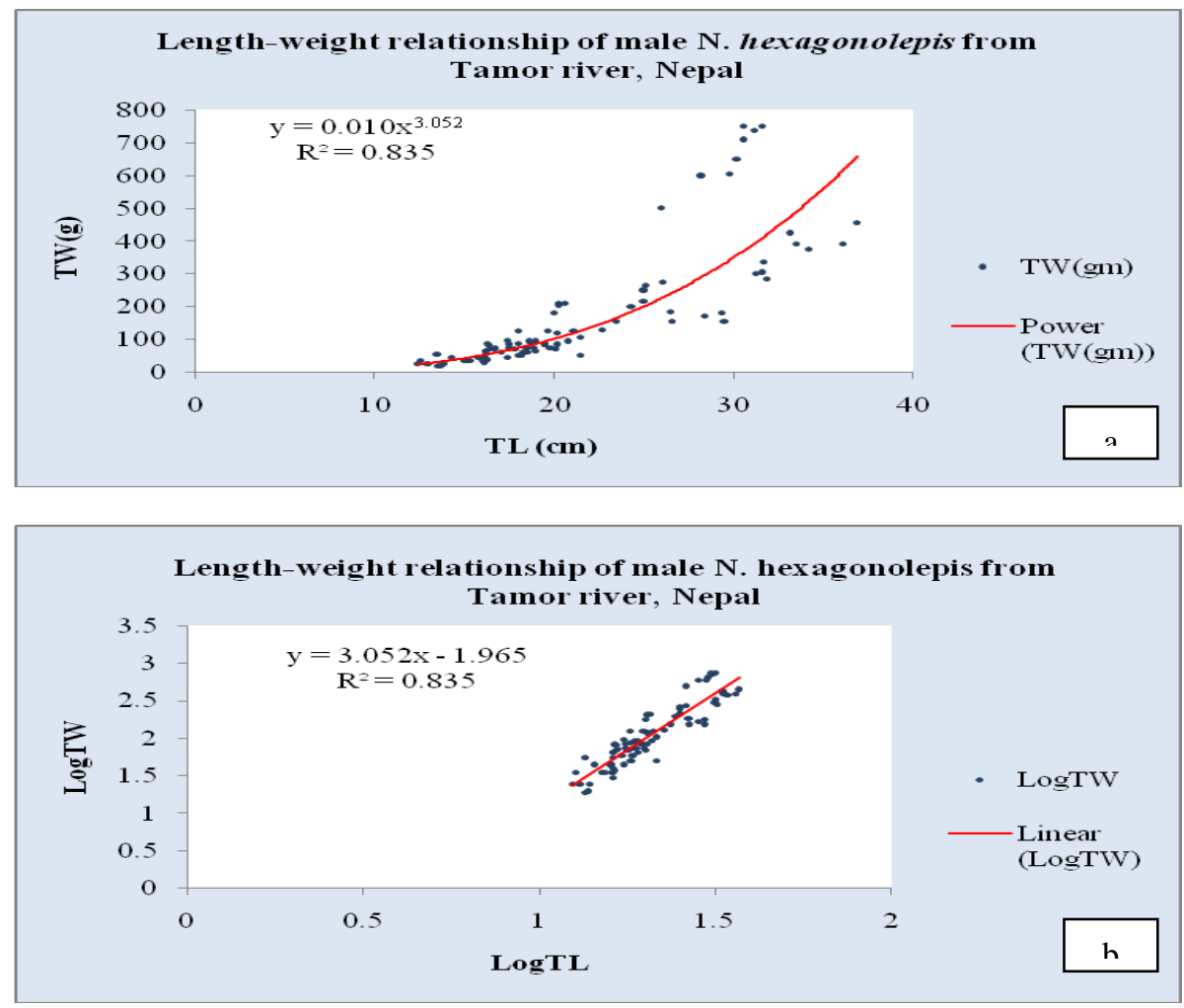

Figure 3. Length- weight relationships of male $N$. hexagonolepis from Tamor river: parabolic form (a) $\mathrm{TW}=0.010 \mathrm{TL}^{3.052}$ and linear form (b) $\log \mathrm{TW}=-1.965+3.052 \log \mathrm{TL}$
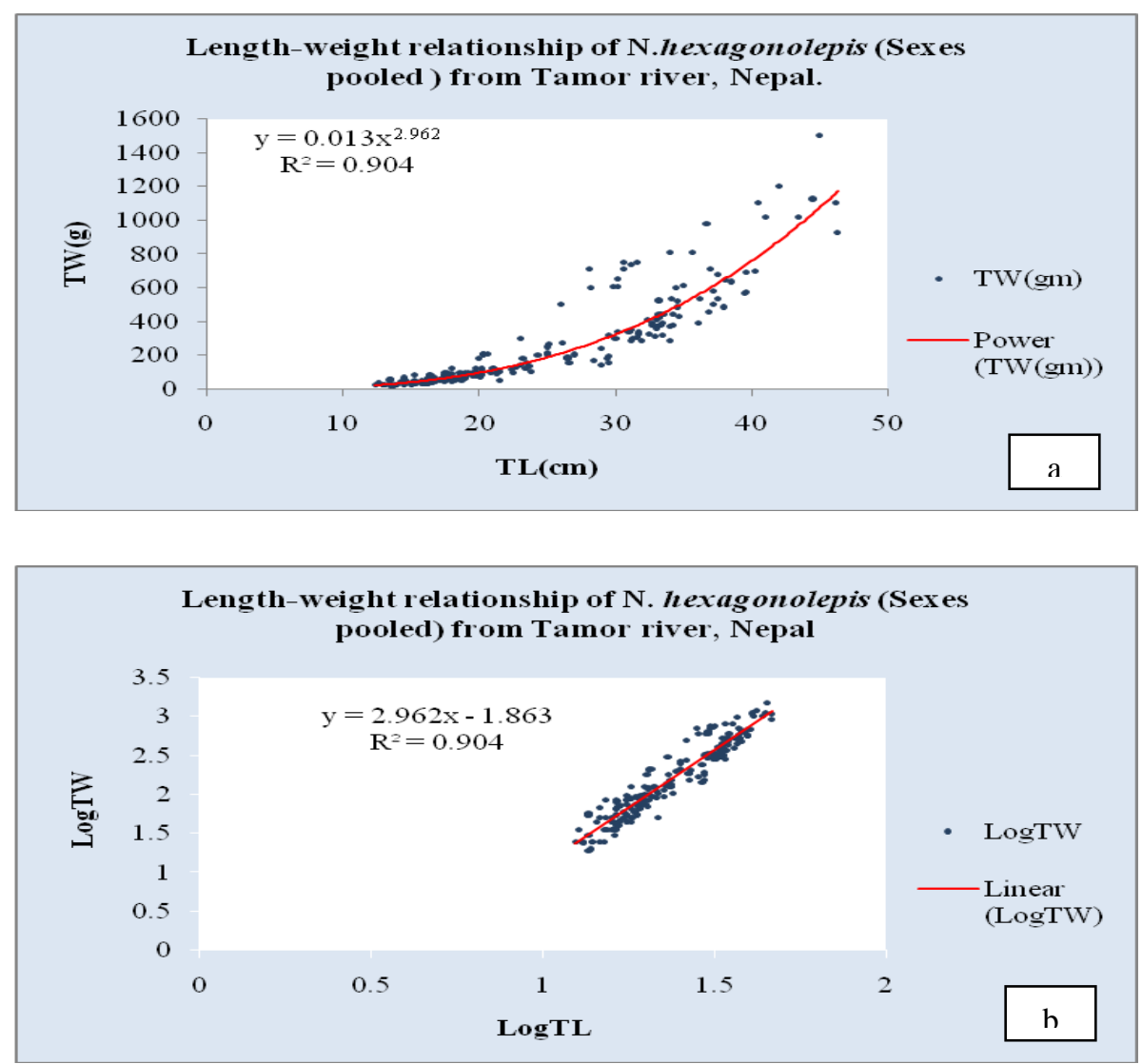

Figure 4. Length- weight relationships of $N$. hexagonolepis (Sexes pooled) from Tamor river: parabolic form (a) $\mathrm{TW}=0.013 \mathrm{TL}^{2.962}$ and linear form (b) $\log \mathrm{TW}=-1.863+2.962 \log \mathrm{TL}$ 


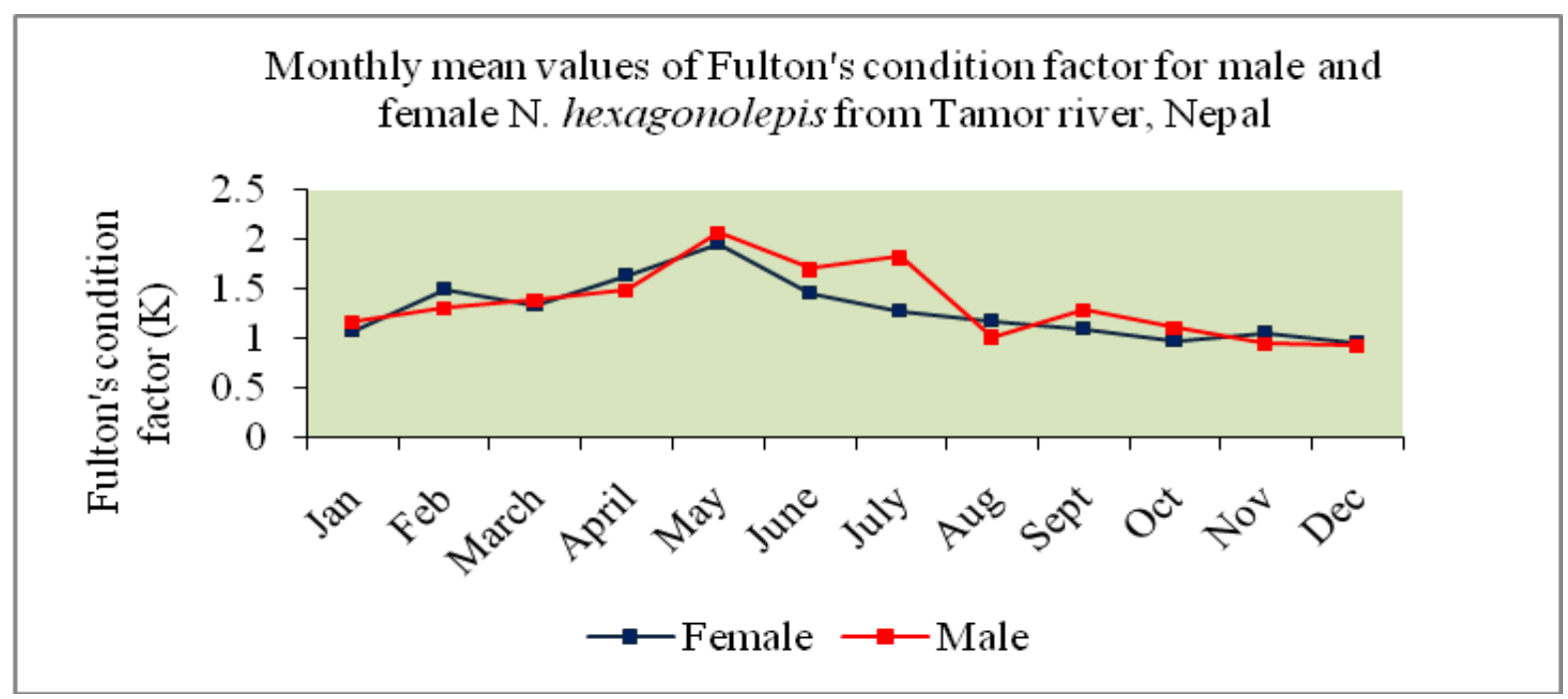

Figure 5. Monthly values of Fulton's condition factor $(\mathrm{K})$ for male and female N. hexagonolepis from Tamor River, Nepal

Male showing higher value of condition factor compared to female gave the indication that, sexwise, the general well-being of male fishes was better than female fishes. This may be attributed to the appetite condition and higher feeding intensity of male fishes. Khallaf et al. (2003) also opined that the condition factor of fish can be affected by a number of factors such as stress, sex, season, availability of feeds and other water quality parameters.

The highest and lowest values of Fulton's condition factor were observed in the month of May and December, respectively, for both the sexes (Fig. 5)

Barnham et al. (2003) suggested that the value of condition factor is greatly influenced by the stage of development of the reproductive organs and with females its value will decrease rapidly when the eggs are shed.

In male fish the value of relative condition factor $(\mathrm{Kn})$ remained comparatively low in size group upto $27-30 \mathrm{~cm}$ but suddenly increased in size group $30-33 \mathrm{~cm}$. This may be due to the increased development of the gonad and therefore indicated the length of the male fish at first maturity. Arunachalam (2010) reported that the male of N. hexagonolepis mature at an early size of $9 \mathrm{~cm}$. On the other hand, the $\mathrm{Kn}$ values for female showed clear cut increasing trend from $30-33 \mathrm{~cm}$ size group indicating the initiation of maturation of gonads and reaching the peak in the size group $42-45 \mathrm{~cm}$. Females in the size range $45-48 \mathrm{~cm}$, exhibiting a sharp decline in $\mathrm{Kn}$ value, represented their spent phase condition.

\section{Acknowledgements}

The authors are grateful to the local fishermen who supported the research by continuously supplying the fish samples from the river.

\section{References}

Abobi, S.M. 2015. Weight-length Models and Relative condition factors of nine (9) freshwater fish species from the Yapei stretch of the white Volta, Ghana. Elixir Appl. Zoology 79: 3042730431.

Adaka, G.N., E. Ndukwe and A. Nlewadim 2017. Length-weight relationship of some fish species in a Tropical Rainforest River in South-East Nigeria. Transylvanian Review of Systematical and Ecological Research 17(2): 73-78.

Araneda, M.,E.P. Perez and L.E. Gasca 2008. White shrimp Penaeus vannamei culture in fresh water at three densities:condition state based on length and weight. Aquacult.283: 13-18.

Arunachalam, M.2010. Neolissochilus hexagonolepis. The IUCN Red list of threatened species 2010: e. T166479A6217872.http:// dx.doi.org/10.2305/IUC N.UK2010-4.RLTS.T166479A6217872.en. (Accessed: 2018.07.31)

Barnham, A. C., F.A. Baxter and Victoria 2003. Condition factor, $K$, for Salmonid fish. (Melbourne): Dept. of Primary Industries

Brody, S. 1945. Bioenergetics and growth. Reinhold Publishing Corporation. New York. 1023p.

Dars, B.A., N.T. Narejo and A. Dayo 2010. Relative condition factor and length-weight relationship of a carp, Labeo gonius (hamilton) from Keenjhar Lake, district Thatta, Sindh, Pakistan. Sindh Univ. Res. Jour. (Sci. Ser.) 42 (2): 67-70.

Das, S., M.A. Barbhuiya, R.I. Barbhuiya and D. Kar 2017. A study on the length -weight relationship and relative condition factor in Glossogobius 
giuris found in river Singla in the Karimganj district of Assam, India. ISOR Journal of Agriculture and Veterinary Science. 10(4): 67-69.

Devashish,K., B. A. Laskar, D. Nath and M.H. Barbhuiya 2005. Length-weight relationship of Neolissocheilus hexagonolepis (Mc Clelland) and Garra lissorhynchus (Mc Clelland). Indian Journal of Fisheries. 52 (4): 495-496.

Google maps 2014. Royal Roads University. Retrieved https://www.google.com/maps/d/viewer?mid= ziZA4YH0pTUs.ktJc02G0F-O4 and ie = UTF8 \& oe $=$ UTF\& \& msa $=0$

Jyrwa, L.B. and R.N. Bhuyan 2017. Histological studies of gonads in Neolissochilus hexagonolepis (McClelland,1839) (Teleostei: Cyprinidae) from Meghalaya, India. Iran. J. Ichthyol. 4(2):140-149.

Hossain, Md. Yeamin 2010. Morphometric Relationships of Length- weight and Lengthlength of four Cyprinid small Indigenous Fish species from the Padma River (NW Bangladesh).Turkish Journal of Fisheries and Aquatic Sciences 10: 131-134.

Khallaf, E., M. Galal and M. Athuman 2003. The biology of Oreochromis niloticus in a polluted canal. Ecotoxicology 12: 405-416.

Kumar, H., B.R. Kiran, R. Purushotham, E.T. Puttaiah and S. Manjappa 2005. Length-weight relationship of cyprinid fish, Rasbora daniconius (Hamilton-Buchanan) from Sharavathi Reservoir, Karnataka. Zoos' Print Journal. 21 (1): 21402141.

Lagler, K.F. 1952. Freshwater fishery biology. Dubyqu. Iowa: W.M.C. Brown Company.

Le Cren, E.D. 1951: The length-weight relationships and seasonal cycle in gonad weight and condition in the perch (Perca fluviatilus). J. Anim. Ecol. 20: 201-219.

Lydia, J, R.N. Bhuyan and R. Nath 2015. Lengthweight relationship and condition factor of Neolissochilus hexagonolepis (Mc Clelland) in Meghalaya, India: A comparative study. International Journal of Fisheries and Aquatic Studies 3 (1): 419-422.

McDowall, R.M. 1994. On size and growth in freshwater fish. Ecology of freshwater fish. 3(2): 67-79.

Ozcan, G and A. Altun 2015. Length-weight relationship and condition factor of three endemic and threatened freshwater fishes from Orontes river. Pakistan J. Zool. 47(6): 1637-1643.

Pathak, S.C. 1975. Length-weight relationship, condition factor and food study of Labeo calbasu (Ham.) from Loni reservoir (M.P.). J. Inland Fish. Soc. India. 8: 58-64.

Pervin, M.R. and M.G., Mortuza 2008. Notes on length-weight relationship and condition factor of fresh water fish, Labeo boga (Hamilton) (Cypriniformes: Cyprinidae). Univ J Zool Rajshahi Univ. 27: 97-98.

Prasad, G. and P.H.Anvar Ali 2007. Length- weight relationship of a cyprinid fish Puntius filamentosus from Chalakudy River, Kerala. Zoos' Print Journa. 22 (3): 2637-2638.

Shrestha, J., D.M. Singh and T.B.Saund 2009. Fish diversity of Tamor river and its major tributaries of eastern Himalayan region of Nepal. Nepal Journal of Science and Technology 10: 219-223.

Swar, D. 1994. A study on the ecology of Katle, Neolissocheilus hexagonolepis (Mc Clelland) in a Nepalese reservoir and river. Department of zoology.Winnipeg, Manitoba: The University of Manitoba. (PhD Thesis) 